\title{
Cheiradone: a vascular endothelial cell growth factor receptor antagonist
}

\author{
Sajjad Hussain ${ }^{1}$, Mark Slevin ${ }^{1}$, Mohammad A Mesaik ${ }^{3}$, \\ Mohammad I Choudhary ${ }^{3}$, Abdul H Elosta ${ }^{1}$, Sabine Matou ${ }^{1}$, Nessar Ahmed ${ }^{1}$, \\ David West ${ }^{2}$ and John Gaffney*1
}

\begin{abstract}
Address: ${ }^{1}$ School of Biology, Chemistry and Health Science, Manchester Metropolitan University, Chester St. Manchester M1 5GD, UK, ${ }^{2}$ School of Biological Sciences, University of Liverpool, Liverpool, L69 7ZB, UK and ${ }^{3}$ H.E.J. Research Institute of Chemistry, International Centre for Biological and Chemical Sciences, University of Karachi, Karachi 75720, Pakistan

Email: Sajjad Hussain - sajjad.hussain@mmu.ac.uk; Mark Slevin - M.A.slevin@mmu.ac.uk; Mohammad A Mesaik - mmesaik@hotmail.com; Mohammad I Choudhary - hej@cyber.net.pk; Abdul H Elosta - a.elosta@mmu.ac.uk; Sabine Matou - s.matou@mmu.ac.uk;

Nessar Ahmed - n.ahmed@mmu.ac.uk; David West - westie@liverpool.ac.uk; John Gaffney* - J.Gaffney@mmu.ac.uk

* Corresponding author
\end{abstract}

Published: 29 January 2008

BMC Cell Biology 2008, 9:7 doi:10.1 186/1471-2121-9-7

This article is available from: http://www.biomedcentral.com/I47I-2/2I/9/7

(c) 2008 Hussain et al; licensee BioMed Central Ltd.

This is an Open Access article distributed under the terms of the Creative Commons Attribution License (http://creativecommons.org/licenses/by/2.0), which permits unrestricted use, distribution, and reproduction in any medium, provided the original work is properly cited.

\begin{abstract}
Background: Angiogenesis, the growth of new blood vessels from the pre-existing vasculature is associated with physiological (for example wound healing) and pathological conditions (tumour development). Vascular endothelial growth factor (VEGF), fibroblast growth factor-2 (FGF-2) and epidermal growth factor (EGF) are the major angiogenic regulators. We have identified a natural product (cheiradone) isolated from a Euphorbia species which inhibited in vivo and in vitro VEGFstimulated angiogenesis but had no effect on FGF-2 or EGF activity. Two primary cultures, bovine aortic and human dermal endothelial cells were used in in vitro (proliferation, wound healing, invasion in Matrigel and tube formation) and in vivo (the chick chorioallantoic membrane) models of angiogenesis in the presence of growth factors and cheiradone. In all cases, the concentration of cheiradone which caused $50 \%$ inhibition $\left(\mathrm{IC}_{50}\right)$ was determined. The effect of cheiradone on the binding of growth factors to their receptors was also investigated.

Results: Cheiradone inhibited all stages of VEGF-induced angiogenesis with $\mathrm{IC}_{50}$ values in the range 5.20-7.50 $\mu \mathrm{M}$ but did not inhibit FGF-2 or EGF-induced angiogenesis. It also inhibited VEGF binding to VEGF receptor-I and 2 with $\mathrm{IC}_{50}$ values of 2.9 and $0.6 \mathrm{I} \mu \mathrm{M}$ respectively.

Conclusion: Cheiradone inhibited VEGF-induced angiogenesis by binding to VEGF receptors -I and -2 and may be a useful investigative tool to study the specific contribution of VEGF to angiogenesis and may have therapeutic potential.
\end{abstract}

\section{Background}

Angiogenesis, the growth of new blood vessels from the existing vasculature is associated with physiological (wound healing, endometrial cycle and embryonic devel- opment) and pathological processes (tumour growth, rheumatoid arthritis, diabetic retinopathy, and brain and cardiac infarctions) $[1,2]$. Angiogenesis is mediated by pro-angiogenic factors including vascular endothelial cell 
growth factor (VEGF), fibroblast growth factor-2 (FGF-2), angiopoietin, and epidermal growth factor (EGF) [3-6].

VEGF comprises a family of multifunctional cytokines which include the variants VEGF-A, -B, -C, -D and-E and placental growth factor (PlGF) $[7,8]$. VEGF-A is mitogenic in vitro and angiogenic in vivo $[9,10]$ and its role in angiogenesis and vasculogenesis has been elucidated [11-13]. At least nine different isoforms of human VEGF-A have been identified with 121, 145, 148, 162, 165, 183, 189 and 206 amino acid residues $[14,8]$. Of these, VEGF ${ }_{165}$ is most clearly associated with pathological angiogenesis [8] and exerts its biological action upon binding with two high affinity receptor tyrosine kinases; VEGFR-1 (flt-1) and VEGFR-2 (kinase domain receptor; flk-1) [8,15]. The role of these receptors, especially flk- 1 in angiogenesis has been confirmed through gene knockout studies and flk-1/- embryos are unable to form blood islands and to generate haematopoietic precursors [reviewed in [16]]. VEGFR1 has a 50 times higher binding affinity for VEGFR-1 than VEGFR-2 [17] however, VEGFR-2 has a stronger receptor tyrosine kinase activity than VEGFR-1 and acts as a major mitogenic receptor on endothelial cells (ECs) $[16,18]$.

Due to the central role of angiogenesis in tumour growth and progression it has been a target in cancer therapy. For example Bevacizumab, a VEGF-A blocking antibody has been approved for the treatment of metastatic colorectal cancer [19] and Sunitinib, a VEGF receptor antagonist for treatment of gastrointestinal stromal tumours and for advanced renal cell carcinoma [20]. Several other VEGF inhibitors including the receptor tyrosine kinase inhibitors (RTKIs), Pegaptanib and Sorafenib have been tested in phase-1 to phase-III clinical trials against VEGF-associated malignancies [21,22].

Natural compounds from medicinal plants display diverse pharmacological activities [23] and have advantages over synthetic drugs, such as smoother action, better tolerance and fewer allergic reactions. Cheiradone, a naturally occurring plant diterpene, was isolated from the medicinal plant Euphobia chiradenia and in preliminary screening was shown to be a PLA 2 inhibitor, have antiinflammatory properties and inhibit wound healing although the mechanisms of action were not investigated [24].

In this study we have investigated the effect of cheiradone on VEGF-induced angiogenesis and show VEGF ${ }_{165}$ binding to VEGFR-1 and -2 resultined in inhibition of in vitro and in vivo angiogenesis.

\section{Results}

Cheiradone inhibited VEGF ${ }_{165}$ binding to VEGFR-I and -2 Cheiradone was found to specifically inhibit the binding of VEGF ${ }_{165}$ to VEGFR-1 and VEGFR-2 in a dose dependent manner with $\mathrm{IC}_{50}$ values of $2.9 \pm 0.31 \mu \mathrm{M}$ and $0.61 \pm 0.14$ $\mu \mathrm{M}$ respectively (Figure 1 ; Table 1 ). No significant inhibition of FGFR-1 and - 2 was observed even at the highest concentration $(328.20 \mu \mathrm{M})$ tested (data not included).

\section{Cheiradone inhibited VEGF-induced EC proliferation}

Cheiradone was tested to evaluate its effect on cell proliferation in the presence of VEGF, EGF and FGF-2. A concentration-dependent inhibition of VEGF-stimulated BAEC and HDMEC proliferation with $\mathrm{IC}_{50}$ values of $7.4 \pm$ 0.74 and $7.8 \pm 1.2 \mu \mathrm{M}$ respectively $(\mathrm{p}<0.005)$ (Figure 2 ; Table 1) was observed. However, no significant inhibition of FGF-2- and EGF-triggered cell proliferation was observed (data not included).

\section{Cheiradone inhibited VEGF-induced EC Migration}

The effect of cheiradone on the migration of ECs was analysed using both two- and three-dimensional cell migration assays. In the two-dimensional assay, a woundhealing model was used to assess the migratory behaviour of BAECs and HDMECs (Figure 3). In the VEGF treated control group, significant wound healing was found $24 \mathrm{~h}$ after the cell monolayer was wounded with a sterile razor blade (Figure 3Biv; results shown for HDMEC). No significant inhibition was observed on non-stimulated wound recovery (Figure 3Biii) However, VEGF- stimulated

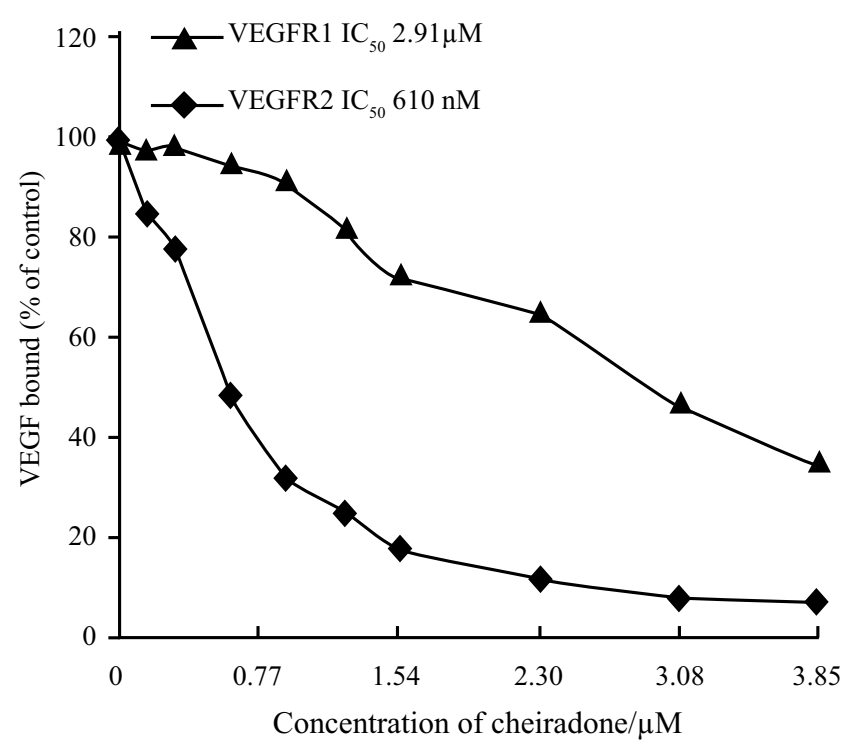

Figure I

Cheiradone inhibits VEGF binding to VEGFR-I and -2 . Cheiradone was incubated with VEGFR-I and VEGFR-2 in the presence of cheiradone $(0-3.85 \mu \mathrm{M})$ and the binding of VEGF $_{165}$ was measured as described above. 
Table I: A summary of the anti-angiogenic properties of cheiradone. $I C_{50}$ values are The mean of three determinations.

\begin{tabular}{lcc}
\hline \multicolumn{1}{c}{ Experiment } & IC $_{\mathbf{5 0}}$ value \pm SEM $(\mu$ M) & HDMEC \\
\hline & BAEC & \\
\hline VEGF-RI binding & $2.9 \pm 0.031$ & $7.4 \pm 0.74$ \\
VEGF-R2 binding & $0.61 \pm 0.14$ & $6.50 \pm .0 .97$ \\
VEGF induced Proliferation & $7.8 \pm 1.2$ & $5.20 \pm 0.38$ \\
Effect on VEGF-induced wound healing & $7.1 \pm 0.77$ & $6.0 \pm 0.38$ \\
Effect on VEGF-induced migration & $7.5 \pm 0.92$ & $8.3 \pm 1.0$ \\
Effect on VEGF-induced tube formation & $7.7 \pm 1.5$ & NS \\
Effect on VEGF-induced invasion & $6.3 \pm 0.31$ & NS \\
Toxicity MTT & NS & NS \\
Toxicity Caspase-3 & & \\
\hline
\end{tabular}

- NS = Overall inhibition is less than $50 \%$ and therefore $\mathrm{IC}_{50}$ values cannot be calculated.

HDMEC and BAEC migration was inhibited after $24 \mathrm{~h}$ in a dose dependent manner by cheiradone with $\mathrm{IC}_{50}$ values of $6.5 \pm 0.97$ and $7.1 \pm 0.77 \mu \mathrm{M}$ respectively $(\mathrm{p}<0.05$; Figure $3 \mathrm{~A}$ and $3 \mathrm{Bv})$. In a three-dimensional cell migration assay, BAECs and HDMECs treated with VEGF showed 2.8 and 2.5 fold increase in migration to the lower chamber compared to non-treated cells respectively (Figure 3C). Cheiradone was found to significantly inhibit $(\mathrm{p}=0.001$ in each case) VEGF-induced BAEC and HDMEC migration with $\mathrm{IC}_{50}$ values of $7.5 \pm 0.92$ and $5.2 \pm 0.38 \mu \mathrm{M}$ respectively.

Cheiradone had no effect on FGF-2 or EGF stimulated migration in the concentration range used (results not shown).

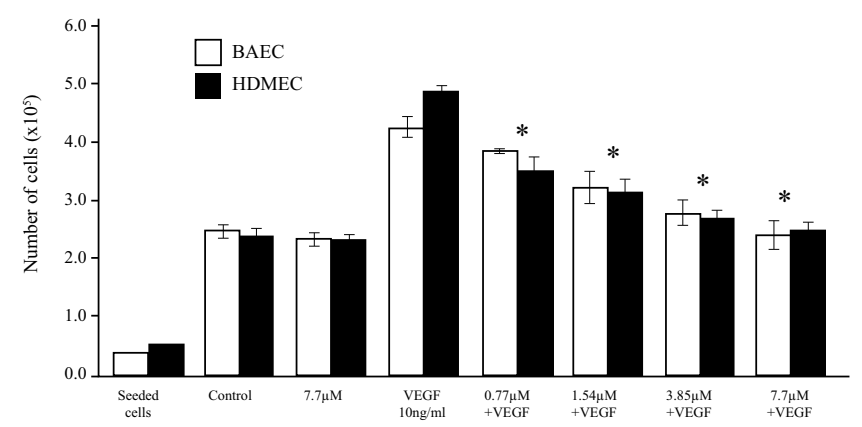

Figure 2

Cheiradone inhibited cell proliferation. Cells were added to a 6-well plate (seeded cells; BAECs $2 \times 10^{4}$ and HDMECs $3 \times$ $\left.10^{4}\right)$ and the effect of cheiradone $(0-7.7 \mu \mathrm{M})$ on VEGF $165(10$ $\mathrm{ng} / \mathrm{ml}$ in each case) induced proliferation was determined as described above. DMSO alone was added to the control and columns 3 and 4 represent cheiradone $(7.7 \mu \mathrm{M})$ or VEGF alone. Values which differ significantly $(p<0.05)$ from VEGF alone are indicated by $*$.

\section{Cheiradone inhibited VEGF-induced EC tube formation}

To examine the role of cheiradone on EC differentiation into vascular structures in vitro, tube formation of BAECs and HDMCs on Matrigel was assessed. When these cells were stimulated with VEGF, elongated tube-like structures were formed and the process was inhibited in a dose dependent manner by cheiradone (Figure 4A). Cheiradone reduced the width and length of VEGF-induced HDMEC and BAEC tubes with $\mathrm{IC}_{50}$ values of $6.0 \pm 0.38$ and $7.7 \pm 1.5 \mu \mathrm{M}$ respectively $(\mathrm{p}<0.005$; Fig $4 \mathrm{Bi}-\mathrm{iv}$, results are shown for HDMEC). No significant effect of cheiradone was seen on non-stimulated tube formation (Figure 4Bii).

\section{Cheiradone inhibited cell invasion}

The effect of cheiradone on cell invasion was analysed using a Transwell Boyden chamber system coated with reconstituted growth factor-reduced Matrigel. BAECs or HDMECs were allowed to invade the lower chamber in the presence and absence of VEGF and cheiradone. A statistically significant increased in cell invasion was observed in VEGF treated HDMECs $(2.2$ fold, $\mathrm{p}=0.002)$ and BAECs ( 3.3 fold, $\mathrm{p}=0.001$ ) (Figure 5). Cheiradone showed dose-dependent inhibition of VEGF stimulated cell invasion of HDMEC and BAEC with $\mathrm{IC}_{50}$ values of 8.3 \pm 1.0 and $6.3 \pm 0.31 \mu \mathrm{M}$ respectively $(\mathrm{p}<0.05)$.

\section{Cheiradone inhibited angiogenesis in the CAM assay}

The above in vitro data suggests that cheiradone inhibits several steps of angiogenesis in vitro. Therefore, we analyzed its effect on in vivo angiogenesis using the CAM assay. After exogenous stimulation of angiogenesis with $\mathrm{VEGF}_{165}$, significant new blood vessel growth was observed towards the stimulus after 6 days (Figure 6C, m $=3, \mathrm{n}=5)$. There was no significant angiogenic response to cheiradone alone (Fig 6B, $\mathrm{m}=0.5, \mathrm{p}=0.0875, \mathrm{n}=5$ ). VEGF $_{165}$-induced blood vessels formation was completely abolished in the presence of cheiradone $(\mathrm{m}=0, \mathrm{n}=5, \mathrm{p}=$ 
A

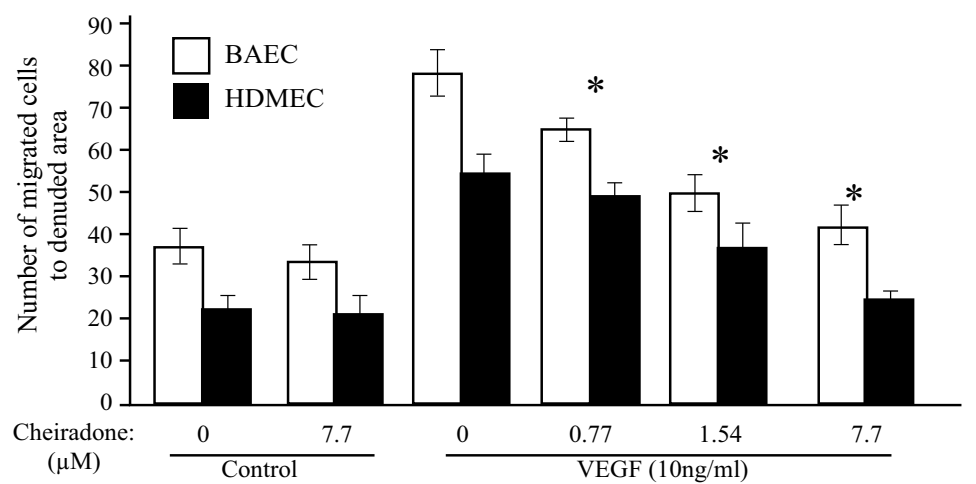

B
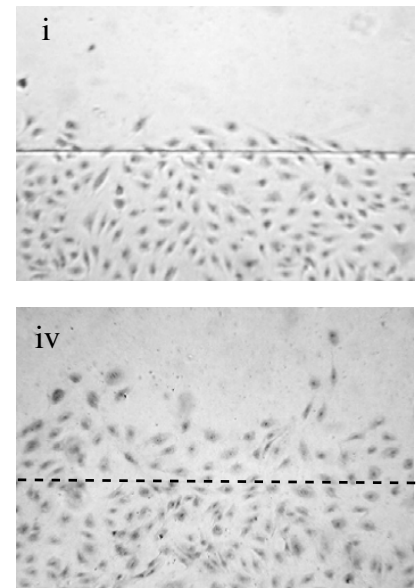
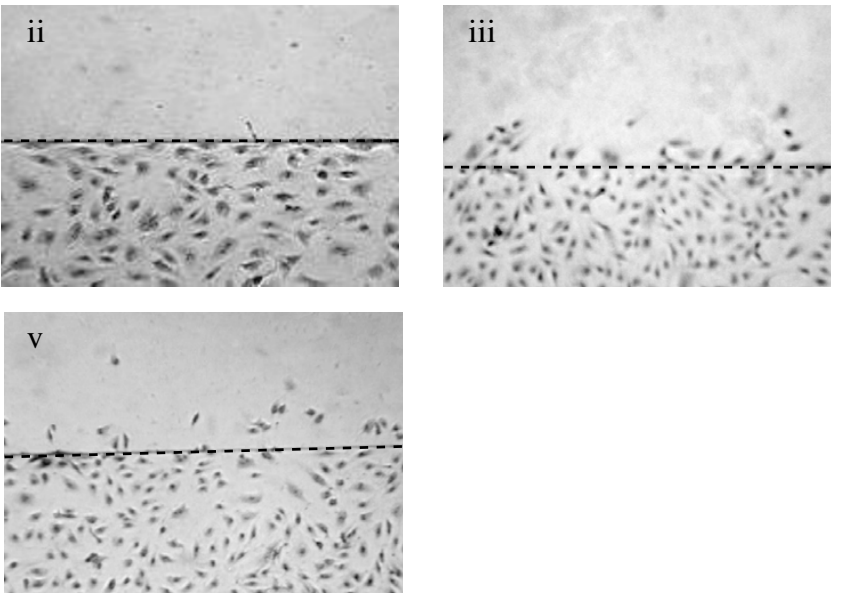

C

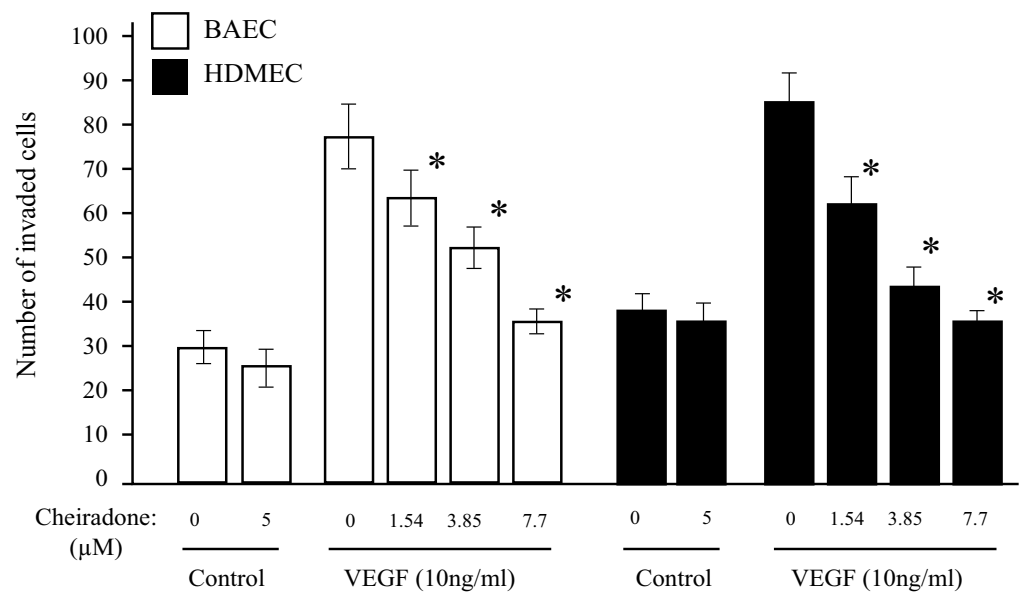

Figure 3

Cheiradone inhibited cell migration. (A) A cell monolayer was wounded as described and recovery was assessed in the presence of increasing concentration of cheiradone $(0-7.7 \mu \mathrm{M})$ and $\operatorname{VEGF}_{165}(10 \mathrm{ng} / \mathrm{ml}$ in all cases). Controls without VEGF contained either DMSO or cheiradone $(7.7 \mu \mathrm{M})$. Values significantly different from VEGF alone $(p<0.05)$ are shown by * $(\mathbf{B})$ Representative photomicrographs show the results for HDMEC: i control, DMSO alone; ii time zero control; iii cheiradone $7.7 \mu \mathrm{M}$; iv treated with VEGF $165 ; 10 \mathrm{ng} / \mathrm{ml}$, $\mathbf{v}$ cheiradone + VEGF. (C) The effect cheiradone on VEGF-induced cell migration in a three dimensional Boyden chamber assay. Cells were added to the upper chamber and the cheiradone $(0-7.7 \mu M)$ with and without VEGF $(10 \mathrm{ng} / \mathrm{ml})$ were added to the lower part. The total number of migrated cells to the lower chamber was counted as described above. Controls without VEGF contained either DMSO or cheiradone $(5 \mu \mathrm{M})$. Values significantly different from VEGF alone $(p<0.05)$ are shown by *. 
A

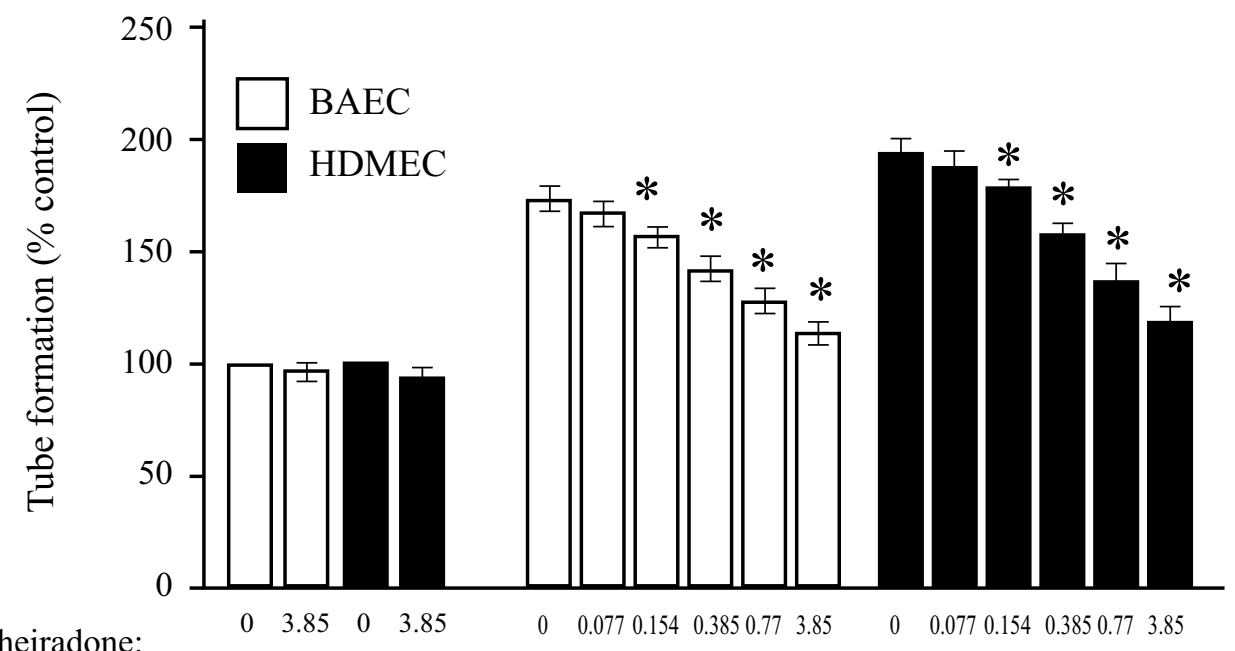

Cheiradone: $(\mu \mathrm{M})$

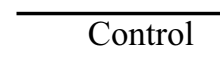

VEGF (10ng/ml)

B

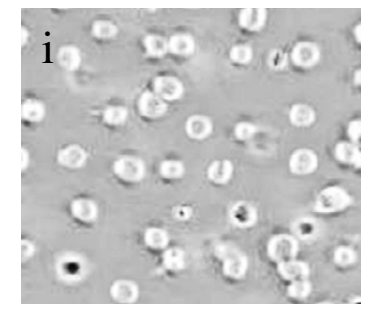

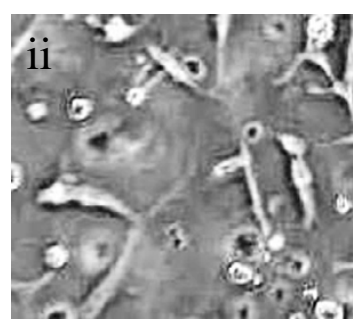

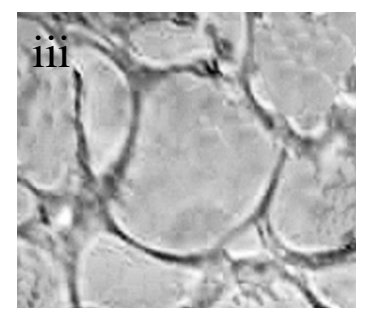

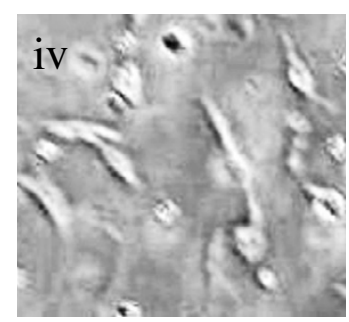

Figure 4

(A) Cheiradone inhibits EC differentiation into capillary like structures on Matrigel. Cells were treated with either cheiradone (control, 0-3.85 $\mu \mathrm{M})$ or cheiradone $(0-3.85 \mu \mathrm{M})$ with VEGF $(10 \mathrm{ng} / \mathrm{ml})$. Values significantly different from VEGF alone $(\mathrm{P}<$ 0.05) are shown by *. (B) Representative photomicrographs show; i HDMEC, ii HDMEC treated with cheiradone; $7.7 \mu M$, iii HDMEC treated with VEGF $10 \mathrm{ng} / \mathrm{ml}$, iv HDMEC treated with VEGF and cheiradone, $7.7 \mu M$. Experiments were performed and the number of closed tubes was determined as described above. Results are the mean of three experiments. Incomplete tube formation was noted in the presence of cheiradone (ii) but extensive tube formation with VEGF (iii). In the presence of cheiradone the effect of VEGF was abolished (iv).

0.0001 ) (Figure 6D). There was no evidence of an inflammatory response with cheiradone alone (Fig 6) or in the control (Figure 6A).

\section{Cytotoxicity study}

No significant cytotoxicity was found at the tested concentrations of cheiradone (Figure 7A), whereas staurosporine induced a noticeable cytotoxic effect in the MTT (Figure 7B) and immunofluorescence (Figure 7D) assays.

\section{Discussion}

Sesterterpenes are naturally occurring polyisoprene compounds widely distributed in plants and animals. There is growing interest in these molecules as potential disrupters of protein-protein interactions [25] since many protein interfaces are characterised by extended, flat surfaces and a number of small molecules which interfere with protein-protein binding have been identified [26]. In addition, members of the sesterterpene family have moderate antibacterial activity against Mycobacterium tuberculosis strain $\mathrm{H}(37) \mathrm{Rv}$, inhibit DNA replication [27], are cytotoxic against tumour cell lines [28] and have potent antiplasmodial properties [29].

During angiogenesis, nascent blood vessels grow by sprouting from the existing vasculature by a cascade of events including degradation of the basement membrane, EC migration, proliferation and tube formation [30]. VEGF exerts its angiogenic effect by binding to high affinity receptors on EC. In addition other growth factors, FGF2 and EGF and their corresponding receptors are associated with angiogenesis [31]. 


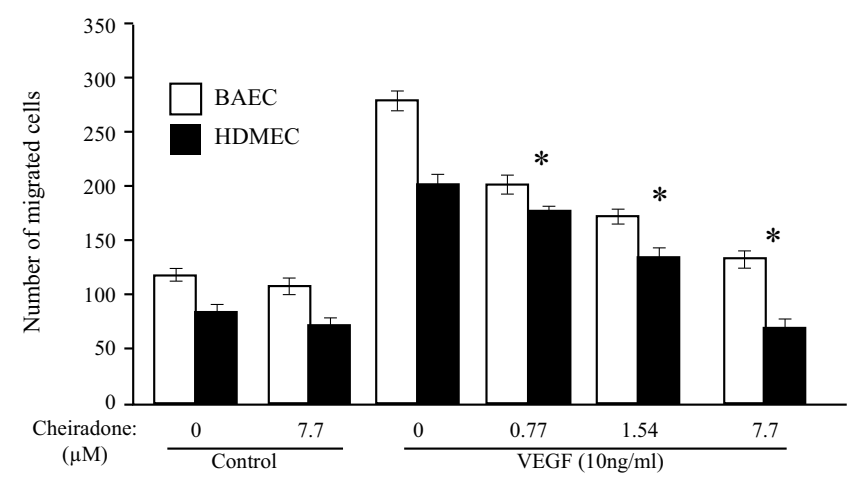

\section{Figure 5}

Cheiradone inhibits cell invasion. The effect of cheiradone on BAEC, and HDMEC cell invasion was studied using the chemoinvasion assay. Cells $\left(1.7 \times 10^{4}\right)$ were added to the Matrigel coated upper Boyden chamber and cheiradone $(0-7.7 \mu \mathrm{M})$ (control) or cheiradone with VEGF $(10 \mathrm{ng} / \mathrm{ml})$ was added to the lower chamber. Cell invasion was measured after $24 \mathrm{~h}$ and assessed as described above. Values significantly different $(p<0.05)$ from VEGF alone are shown by $*$.

In this study, we demonstrated that cheiradone inhibited multiple steps of VEGF-induced angiogenesis in vitro and in vivo. VEGF is the main regulator of angiogenesis and elevated levels have been reported in pathological conditions. The binding of VEGF to high affinity tyrosine kinase receptors such as VEGFR-1 \& 2 activates VEGF-dependent signalling cascades which initiate the early events of angiogenesis (cell proliferation and migration from the lumen of existing vessels). Our in vitro inhibition data showed that cheiradone appeared to inhibit EC proliferation and migration with $\mathrm{IC}_{50}$ values in the range 5.2-7.8 $\mu \mathrm{M}$. In the later stages of angiogenesis, ECs differentiate into tubular like structures that eventually form the lumen of the new vessel. The in vitro Matrigel tube formation assay showed that cheiradone inhibited VEGF-induced tube-like structures at low concentrations. We also demonstrated that cheiradone completely inhibited angiogenesis in vivo using the CAM assay. Therefore, cheiradone appears an effective antagonist of angiogenesis. Cheiradone was equally effective at inhibiting angiogenesis in both large vessel-derived (BAEC) and small vessel-derived cells (HDMEC; the in vivo target of angiogenic modulators).

Binding studies with VEGFR-1 and -2 showed significant inhibition of VEGF binding in the presence of cheiradone, with stronger inhibition of VEGFR-2. When cells were preincubated with cheiradone, and the cheiradone removed prior to addition of VEGF a significant inhibition of cell proliferation was still observed, indicating that cheiradone was not interacting directly with VEGF. Instead cheiradone competed with VEGF for binding to a VEGF
A

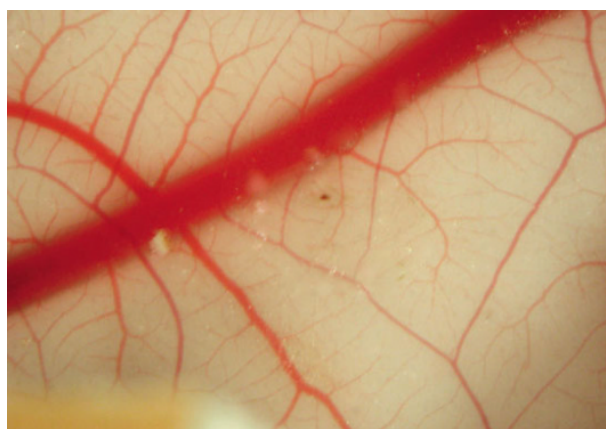

B

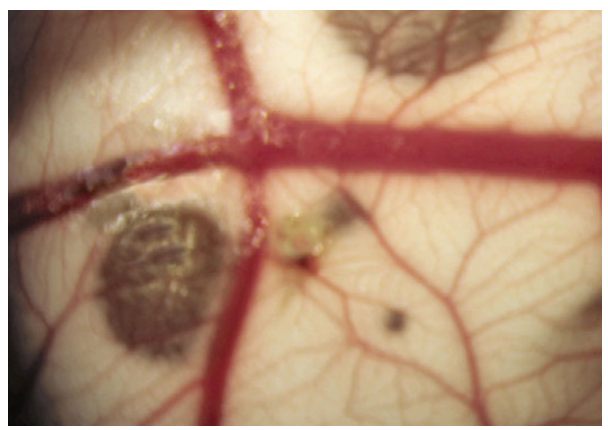

C

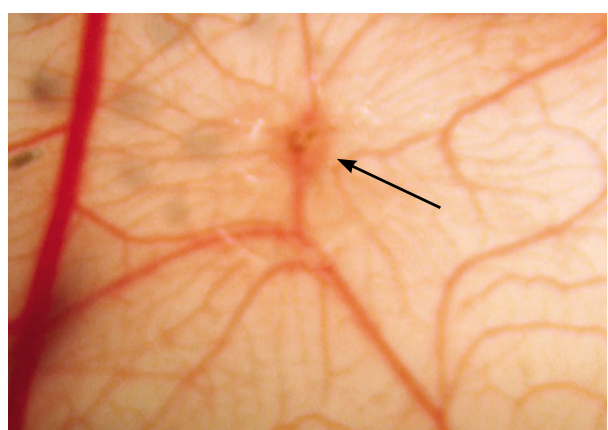

$\mathrm{D}$

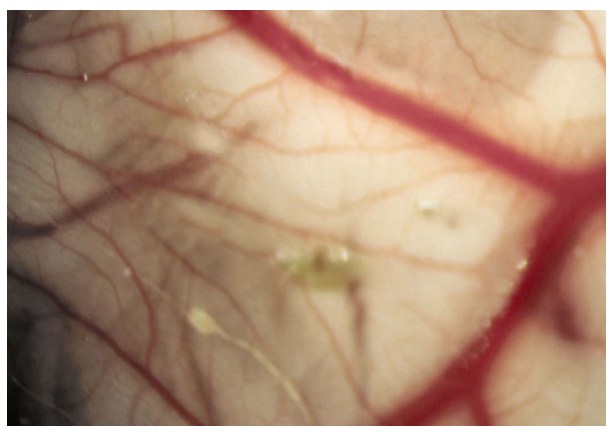

\section{Figure 6}

Cheiradone inhibits in vivo angiogenesis in the CAM assay. (A) control, methylcellulose alone showed no evidence of angiogenesis or inflammation (B) cheiradone ( $10 \mu \mathrm{g})$ failed to induce blood vessel formation (C) VEGF, a network of new blood vessels was established (see arrow) at the point of application. (D) cheiradone (10 $\mu \mathrm{g})+$ VEGF inhibited vessel formation. There was no evidence of an inflammatory response in any preparation. Representative photomicrographs are shown. Magnification $\times 50$. 


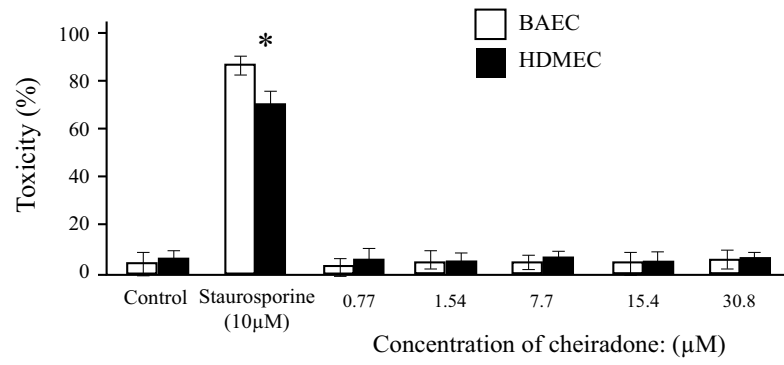

B

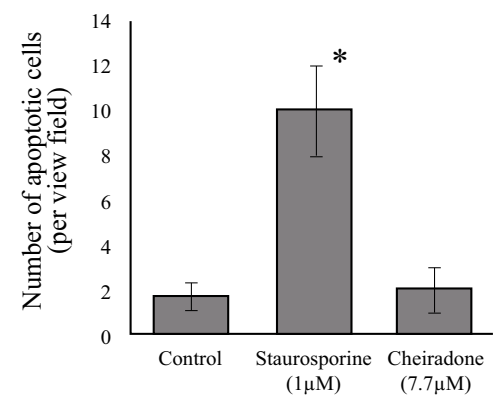

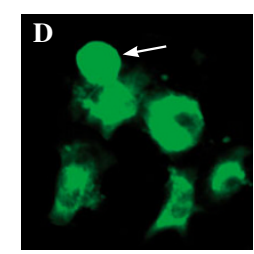

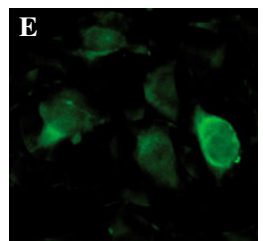

\section{Figure 7}

Investigation of the cytotoxic effect of cheiradone on BAEC and HDMEC viability. The cytotoxic effect of cheiradone was determined using (A) MTT assay and (B) Active-caspase-3 apoptosis assay. Cells were incubated with cheiradone and staurosporine (I.4 $\mathrm{MM})$ for $24 \mathrm{~h}$. Values significantly different from the control (DMSO) are shown by *. Immunofluorescence photomicrographs for HMDEC were taken as described above and show. (C) control, DMSO (D staurosporine, the arrow indicates a positively stained apoptotic cell and (E) cheiradone.

receptor. Both VEGFR-1 and -2 contain extracellular, juxtamembrane and tyrosine kinase domains. We have no evidence which domain cheiradone binds to and are currently investigating the tyrosine kinase activity of the VEGF receptors in the presence of the inhibitor. An additional mechanism by which cheiradone can affect VEGFinduced angiogenesis is by regulating the expression levels of VEGFR-1 and/or VEGFR-2. We are currently investigating the interaction of cheiradone with the receptors on endothelial cells.

Semino et al., [32] have developed an in vivo model of angiogenesis in the presence of interstitial flow. They propose a two step model of angiogenesis requiring initial activation by VEGF and subsequent maturation of the new blood vessel on exposure to EGF. Cheiradone would be an ideal molecule to test this model since it has no activity against EGF. In vivo, VEGFR-1 is constitutively expressed in the blood vascular system while VEGFR-2 is down regulated but is over expressed in angiogeneic endothelial cells and after hypoxia [33]. We have shown that cheiradone is more active against VEGFR-2 and may therefore be a more specific molecule for targeting angiogenic blood vessels in diseases such as cancer.

In addition, cytotoxicity studies showed that cheiradone had no adverse effects at concentrations greater than those used in the present study.

The advantage of cheiradone over existing VEGF inhibitors is that it does not remove VEGF from the system and VEGF activity may be modulated by varying the concentration of cheiradone.

\section{Conclusion}

We have demonstrated that cheiradone, a naturally occurring sesterterpene inhibits VEGF-induced angiogenesis by competing with VEGF for VEGFR-1 and -2. There was no activity against FGF-2 or EGF. Further study of the structural relationships of cheiradone and its activity may provide a basis for designing VEGF receptor antagonist with enhanced inhibitory potential and improved specificity.

\section{Methods}

\section{Test compound}

Cheiradone (Fig 8; RMM 613) was extracted and purified from Euphorbia cheiradenia Boiss. Full chemical characterisation and purification is detailed elsewhere [24].

\section{Materials}

Matrigel (Becton Dickinson, UK), FGF-2, goat anti-active caspase-3 antibody (R\&D System), VEGF 165 (Apollo Cytokine Research, Cambridge, UK), EGF, VEGFR-1 and 2 and FGFR-1 and -2, anti-FGF-2 and anti-VEGF antibodies (Santa Cruz Biotechnology, Heidelberg, GDR), ABTS peroxidase substrate kit (Vector, UK), Transwell chamber system, culture plates and flasks (SLS, UK), anti-goat Alexa flour 488 conjugated green fluorescence dye and other chemical of commercial grade were purchased from Sigma (Poole, UK).

\section{Cell Culture}

Human dermal microvascular endothelial cells (HDMECs) and the appropriate medium were purchased from TCS Cellworks (Buckingham, UK) and were cultured and maintained according to the supplier's instructions. Bovine aortic endothelial cells (BAECs) were from an established large vessel primary cell culture obtained and characterised as described previously [34]. They were rou- 


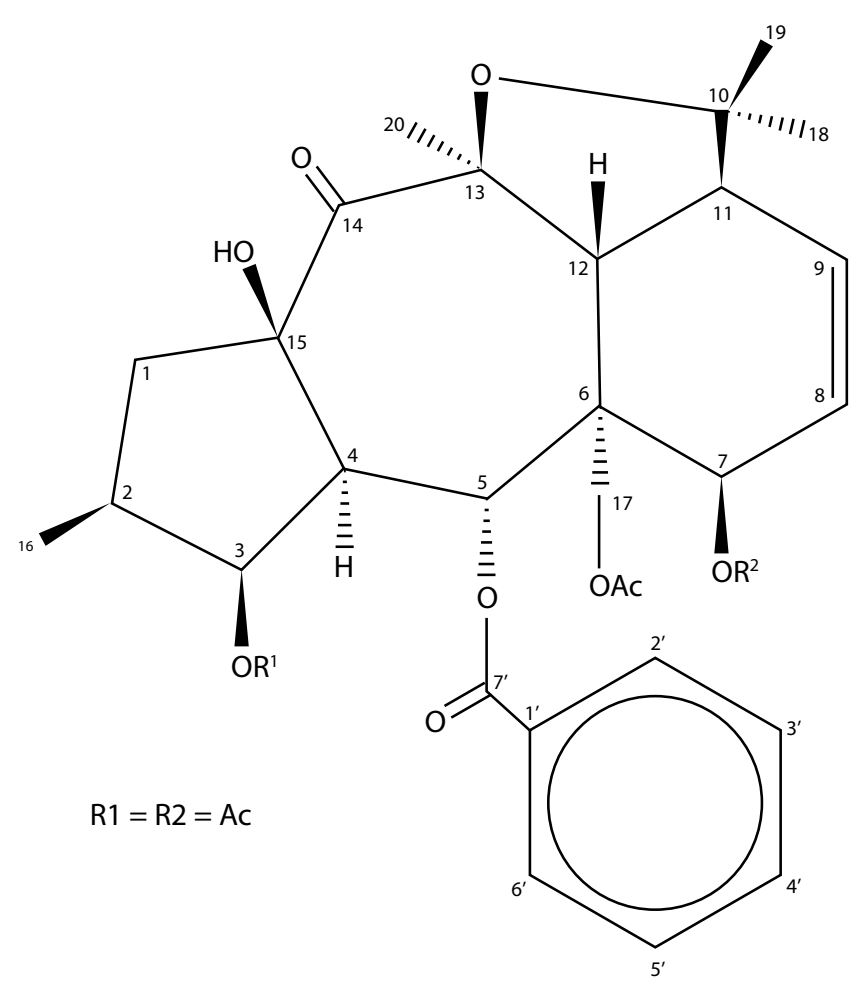

Figure 8

The structure of cheiradone.

tinely cultured in Dulbecco's modified Eagles medium (DMEM) containing varying concentrations of foetal calf serum (FCS). All cells were used between passages six to nine.

\section{Cell proliferation assay}

Cells were seeded in triplicate at a concentration of $2.5 \times$ $10^{4} / \mathrm{ml}$, in $2 \mathrm{ml}$ of complete medium in 6-well plates. After attachment $(24 \mathrm{~h})$, medium was replaced with serum poor medium (SPM), containing $2.5 \%$ foetal calf serum in which the cells grew at a significantly reduced rate. Growth factors FGF-2 and EGF $(25 \mathrm{ng} / \mathrm{ml})$, and $\operatorname{VEGF}_{165}(10 \mathrm{ng} / \mathrm{ml})$ with and without the test compound at different concentrations was added and cells incubated for a further $72 \mathrm{~h}$. Control wells were treated with $5 \mu \mathrm{l}$ DMSO. Concentration ranges of test compounds and preincubation times were based on pilot studies. MTT and immunofluorescence studies using active caspase- 3 as a measure of apoptosis confirmed that test compounds were not cytotoxic at the concentrations used (see below). After $72 \mathrm{~h}$, cells were washed in PBS, detached in $0.05 \% \mathrm{w} /$ $\mathrm{v}$ trypsin in PBS, and counted on a Coulter counter (Coulter Electronics, Hialeah, FL) set to a threshold of $30 \mu \mathrm{m}$. Experiments were performed at least twice in triplicate wells and significance was determined by the Student $t$ test. A representative example is shown.

\section{Cell migration assay}

Cell migration was examined in vitro using a Transwell chamber system with $8.0 \mu \mathrm{m}$ pore polycarbonate filter inserts (TSL, UK). The Transwell insert was coated overnight with $0.1 \% \mathrm{w} / \mathrm{v}$ gelatine, and air-dried. Cells $\left(1 \times 10^{5}\right)$ were placed in the upper part of the filter and test compounds at different concentrations with and without growth factors were added to the lower part in SPM. Cells were incubated at $37^{\circ} \mathrm{C}$ for $16 \mathrm{~h}$. After fixation ( $4 \%$ paraformaldehyde), and staining (Geimsa), cell migration in duplicate wells was determined by counting cell numbers on the lower surface. Experiments were performed at least twice and a representative example is shown. Significance was determined by the Student $t$ test.

\section{Wound healing assay}

Cells $\left(6 \times 10^{4} / \mathrm{ml}\right)$ were added to a Thrermanox cover slip in a 24-well plate in complete medium and incubated for 24-48 h. When confluent, the medium was replaced with DMEM containing $0.1 \%$ FCS and incubated for a further $48 \mathrm{~h}$. Cover slips were washed (PBS, $\times 3$ ), wounded with a sterile razor to produce a straight edged cut and washed in PBS to remove dislodged cells. Cover slips were added to a fresh 24 -well plate in $0.1 \%$ FCS and incubated with VEGF $_{165}$ or the other growth factors and a range of concentrations of test compound for $24 \mathrm{~h}$. Under these conditions there was negligible proliferation but measurable migration. Slides were fixed in ethanol $(100 \%)$, stained with methylene blue and photographed. For each slide, 10 fields of view $(2 \mathrm{~mm} \times 1.45 \mathrm{~mm})$ were counted at random. Each experiment was performed at least twice and significance was determined by the Student $t$ test.

\section{Cell differentiation assays in Matrigel}

Cells $\left(1.0 \times 10^{6} / \mathrm{ml}\right)$ were mixed with an equal volume of Matrigel at $4{ }^{\circ} \mathrm{C}$. Aliquots $(45 \mu \mathrm{l})$ were added to the wells of a 48-well plate and allowed to polymerise $(1 \mathrm{~h})$ when $500 \mu \mathrm{l}$ of microvascular endothelial cell medium containing $\mathrm{VEGF}_{165}$ or the other growth factors, with or without the test compound was added. The cells were incubated for $24 \mathrm{~h}$ at $37^{\circ} \mathrm{C}$ then fixed in $4 \%$ paraformaldehyde $(5$ min), washed in cold ethanol and air dried. Cells were stained with Geimsa (30 sec), air dried and photographed. Ten random fields were selected and the number of closed tubes counted.

All experiments were performed in triplicate and repeated at least twice and significance was determined by the Student $t$ test.

\section{Chemoinvasion assay}

A Transwell cell culture chamber with 6.5-mm-diameter polycarbonate filters ( 8 - $\mu \mathrm{m}$ pore size) were coated with $30 \mu \mathrm{g} / \mathrm{ml}$ Matrigel. Cells $\left(1 \times 10^{5}\right)$ were added to the upper chamber suspended in an appropriate medium. The 
medium containing a range of concentrations of test compound was added to the lower chamber in the presence and absence of $\mathrm{VEGF}_{165}$ or the other growth factors. After $24 \mathrm{~h}$ incubation at $37^{\circ} \mathrm{C}$, the medium from the lower chamber was removed, cell fixed (4\% paraformaldehyde) and stained. The number of cells invaded to the lower chamber through the Matrigel was counted under phasecontrast microscopy. Each invasion experiment was performed in triplicate and repeated at least twice. Statistical significance was determined using the Student $t$ test.

\section{Binding assay}

Competition between growth factors, their cell surface receptors and test compounds was assessed as described previously [35]. A 96-well plate was coated overnight with growth factors ( $2 \mu \mathrm{g} / \mathrm{ml}$ of VEGF VE5 $_{165}$ or FGF-2) and blocked with 1\% BSA in PBS containing 0.05\% Tween-20. The test compound was separately pre-mixed with soluble receptors VEGFR-1, VEGFR-2, FGFR-1 or FGFR-2 $(2 \mu \mathrm{g} / \mathrm{ml}$ in each case) for $2 \mathrm{~h}$ and added to the plate and incubated for a further $2 \mathrm{~h}$. The plate was washed ( $\times 3$ with PBS-Tween$20)$ and incubated with anti-VEGF or anti-FGF-2 antibody (1:500 in PBS-Tween-20) for $45 \mathrm{~min}$, washed and incubated with horseradish peroxidase conjugated goat antiIgG (Santa Cruz, 1:1000) for a further $45 \mathrm{~min}$. After washing $(\times 3)$, ABTS peroxidase substrate (Vector, UK) was added and the absorbance read at $405 \mathrm{~nm}$. $\mathrm{IC}_{50}$ values were calculated from the data using the EZ-Fit enzyme kinetic software (Perella Scientific Inc., Amherst, USA).

\section{Chick chorioallantoic assay}

The angiogenic activity of cheiradone was determined using the semi-quantitative chick chorioallantoic assay (CAM) as described previously [36]. To expose the CAM a window was created in the shells of 4 day-old chicken eggs. On day 8 , a $2 \mathrm{~mm}^{3}$ methycellulose pellet ( $5 \mu \mathrm{l}$ of $1 \%$ sterile methylcellulose; 400 centipoise, Sigma UK) containing no additions (control), the test compound $(10 \mu \mathrm{g})$ with and without VEGF (100 ng) were applied to the membrane. The resultant angiogenesis scored on day 14 as 0 - negative; 0.5 - change in vessel architecture; 1 - partial spokewheel (1/3 of circumference exhibits directional angiogenesis); 2 - spokewheel; 3 or greater-strong and fully spokewheel. This approach enabled calculation of an accumulated response in each group. To photograph the membrane, $2 \mathrm{~cm}^{3}$ of a $50 \%$ emulsion of aqueous paraffin oil containing $2 \%$ Tween- 80 was injected at the site of application and photographed using a Leitz dissecting microscope. Each experiment was performed five times and statistical significance was determined by the MannWhitney $U$ test and the data is expressed as a median value (m).

\section{Toxicity Assays}

Cheiradone toxicity was determined using MTT and active caspase-3 assays. BAECs or HDMECs $\left(7.5 \times 10^{3}\right)$ were seeded in a 96 well plate and incubated for $4 \mathrm{~h}$ to allow cell adhesion. Cheiradone or staurosporine, an inducer of active caspase- 3 and therefore, of apoptosis $(1 \mu \mathrm{M})$ was added to the wells. Control cells were treated with PBS and the plate was incubated at room temperature for 72 hours. MTT reagent $(10 \mu \mathrm{l})$ was added followed by incubation at room temperature for $2-4 \mathrm{~h}$. When a purple precipitate was visible, detergent reagent $(100 \mu \mathrm{l})$ was added to the plates and incubated at room temperature for $2 \mathrm{~h}$ in the dark. Absorbance was measured at $570 \mathrm{~nm}$ using a microplate reader.

In the apoptosis assay, HDMECs or BAEC $\left(4 \times 10^{4} / \mathrm{ml}\right)$ in complete medium were added to the chambers slide and allowed to adhere for $24 \mathrm{~h}$. Cheiradone $(8.2 \mu \mathrm{M})$ or staurosporine $(1 \mu \mathrm{M})$ were added to all wells except control (PBS) and incubated for 24 hours. Wells treated with staurosporine were immediately washed (PBS) and fixed (4\% paraformaldehyde) when cell morphology became round (2-4 h). After washing and fixing, cells were permeablized ( $0.1 \%$ Triton X-100; $10 \mathrm{~min})$, washed ( $\times 5 \sim 5$ min each), air dried and blocked with 1\% BSA in 1:50 TBS Tween for $1 \mathrm{~h}$ at room temperature. Cells were incubated with goat anti-active caspase-3 (R\&D system, UK; 1\% BSA in TBS Tween) for $1 \mathrm{~h}$. The plates were incubated with anti-goat Alexa-Flour 488 conjugated green fluorescent dye for 1.5 $\mathrm{h}$ at room temperature. Ten random homogeneous fields were viewed, and photographed.

\section{Authors' contributions}

$\mathrm{SH}$ carried out the angiogenic assays.

JG, NA and MS participated in the design of the study and preparation of the manuscript. MM, MC and AE isolated and characterised the cheiradone.

SM carried out the experiments on tube formation DW performed the CAM assay. All authors read and approved the manuscript.

\section{Acknowledgements}

We would like to thank the Research Institute of Health and Social Care of Manchester metropolitan University for funding for SJ and M Hoult for assistance in the preparation of the manuscript.

\section{References}

I. Folkman J: Angiogenesis: an organizing principle for drug discovery? Nat Rev Drug Discov 2007, 6:273-86.

2. Hillen F, Griffioen AW: Tumour vascularization: sprouting angiogenesis and beyond. Cancer Metastasis Rev in press. 2007 Aug 24

3. Shima DT, Adamis AP, Ferrara N, Yeo KT, Yeo TK, Allende R, Folkman J, D'Amore PA: Hypoxic induction of endothelial cell growth factors in retinal cells: identification and characterization of vascular endothelial growth factor (VEGF) as the mitogen. Mol Med 1995, I: 182-193. 
4. Li Z, Shimada Y, Uchida S, Maeda M, Kawabe A, Mori A, Itami A, Kano M, Watanabe G, Imamura M: TGF-alpha as well as VEGF, PD ECGF and bFGF contribute to angiogenesis of esophageal squamous cell carcinoma. Int / Oncol 2000, I7:453-460.

5. Milkiewicz M, Ispanovic E, Doyle JL, Haas TL: Regulators of angiogenesis and strategies for their therapeutic manipulation. Int J Biochem Cell iol 2006, 38:333-357.

6. Morisada T, Kubota Y, Urano T, Suda T, Oike Y: Angiopoietins and angiopoietin-like proteins in angiogenesis. Endothelium 2006 , | 3:7|-79.

7. Ferrara N, Gerber HP, LeCouter J: The biology of VEGF and its receptors. Nat Med 2003, 9:669-676.

8. Takahashi $\mathrm{H}$, Shibuya $\mathrm{M}$ : The vascular endothelial growth factor VEGF/VEGF receptor system and its role under physiological and pathological conditions. Clin Sci (Lond) 2005, I09:227-24l.

9. McNamara DA, Harmey J, Wang JH, Kay E, Walsh TN, BouchierHayes DJ: Tamoxifen inhibits endothelial cell proliferation and attenuates VEGF-mediated angiogenesis and migration in vivo. Eur J Surg Oncol 200I, 27:7|4-7|8.

10. Parenti A, Bellik L, Brogelli L, Filippi S, Ledda F: Endogenous VEGF$A$ is responsible for mitogenic effects of MCP-I on vascular smooth muscle cells. Am J Physiol Heart Circ Physiol 2004, 286:HI 978-1984.

II. Liang D, Chang JR, Chin AJ, Smith A, Kelly C, Weinberg ES, Ge R: The role of vascular endothelial growth factor (VEGF) in vasculogenesis, angiogenesis and hematopoiesis in zebrafish development. Mech Dev 200I, 108:29-43.

12. Nagy JA, Dvorak AM, Dvorak HF: EGF-A(164/165) and PIGF: roles in angiogenesis and arteriogenesis. Trends Cardiovasc Med 2003, HKJ: $169-175$.

13. Conejo-Garcia JR, Benencia F, Courreges MC, Kang E, MohamedHadley A, Buckanovich RJ, Holtz DO, Jenkins A, Na H, Zhang L, Wagner DS, Katsaros D, Caroll R, Coukos G: Tumor-infiltrating dendritic cell precursors recruited by a beta-defensin contribute to vasculogenesis under the influence of VEGF-A. Nat Med 2004, 10:950-958

14. Hoeben A, Landuyt B, Highley MS, Wildiers H, Van Oosterom AT, De Bruijn EA: Vascular endothelial growth factor and angiogenesis. Pharmacol Rev 2004, 56:549-580.

15. Eming SA, Krieg T: Molecular mechanisms of VEGF-A action during tissue repair. J Investig Dermatol Symp Proc 2006, I I:79-86.

16. Shibuya M: Vascular endothelial growth factor receptor-I (VEGFR-I/FIt-I): a dual regulator for angiogenesis. Angiogenesis 2006, 9:225-230.

17. Zilberberg L, Shinkaruk S, Lequin O, Rousseau B, Hagedorn M, Costa F, Caronzolo D, Balke M, Canron X, Convert O, Lain G, Gionnet K, Goncalves M, Bayle M, Bello L, Chassaing G, Deleris G, Bikfalvi A: Structure and inhibitory effects on angiogenesis and tumor development of a new vascular endothelial growth factor inhibitor. J Biol Chem 2003, I 2;278:35564-35573.

18. Byrne AM, Bouchier-Hayes DJ, Harmey JH: Angiogenic and cell survival functions of vascular endothelial growth factor (VEGF). J Cell Mol Med 2005, 9:777-794.

19. Kramer I, Lipp HP: Bevacizumab, a humanized anti-angiogenic monoclonal antibody for the treatment of colorectal cancer. J Clin Pharm Ther 2007, 32:1-14.

20. Schneider Bryan P, Sledge George W Jr: Drug Insight: VEGF as a therapeutic target for breast cancer. Nature Clinical Practice Oncology 2007, 4: 18I-189.

21. Cabebe E, Fisher GA: Clinical trials of VEGF receptor tyrosine kinase inhibitors in pancreatic ccancer. Expert Opin Investig Drugs 2007, 16:467-476.

22. Gridelli C, Maione P, Del Gaizo F, Colantuoni G, Guerriero C, Ferrara C, Nicolella D, Comunale D, De Vita A, Rossi A: Sorafenib and sunitinib in the treatment of advanced non-small cell lung cancer. Oncologist 2007, I2:19|-200.

23. Lovkova M, Ya GN, Buzuk SM, Sokolova NI, Kliment'eva : Chemica Features of Medicinal Plants (Review). Applied Biochemistry and Microbiology 200I, 37:229-237.

24. Abbas M, Jassbi AR, Zahid M, Ali Z, Alam N, Akhtar F, labal Choudhary M, Ahmad Viqar Uddin: Three new diterpenoids from Euphorbia cheiradenia. Helvetica Chimica Acta 2000, 83:275I-2755.
25. Schade $M$, Oschkinat $H$ : NMR fragments screening: tackling protein-protein interaction targets. Curr Opin Drug Discovery Dev 2005, 8:365-373.

26. Eyckerman S, Lemmens I, Catteeuw D, Verhee A, Vandekerckhove J, Lievens S, Tavernier : Reverse MAPPIT: screening for proteinprotein interaction modifiers in mammalian cells. Nat Methods 2005, 2:427-433.

27. Choi HJ, Choi YH, Yee SB, Im E, Jung JH, Kim ND: Incinin-I induces cell cycle arrest and apoptosis in SK-MEL-2 human melanoma cell lines. Mol Carcinog 2005, 44:162-173.

28. Petit GR, $\tan R$, Cichacz ZA: Antineoplastic agent 542. Isolation and structure of sesterstatin from the Indian Ocean sponge Hyrtios erecta. J Nat Prod 2005, 68: I253-I255.

29. Kirsch G, Kong GM, Wright AD, Kaminsky R: A new bioactive sesterterpene and antiplasmodial alkaloid from the marine sponge hyrtios cf. erecta. J Nat Prod 2000, 63:825-829.

30. Klagsprun M, Folkman J: Peptide growth factors and their receptors Edited by: Sporn MB, Roberts AB. Springer, NY; 1990:549-586.

31. Dunn I, Heese $O$, Blach $P$ : growth factors in glioma angiogenesis: FGFs, PDGF, EGF and TGFs. I Neuro-Oncol 2000, 50:121-137.

32. Semino CE, Kamm RD, Lauffenberger DA: Autocrine EGF receptor activation mediates endothelial cell migration and vascular morphogenesis by VEGF under interstitial flow. Exp Cell Res 2006, 3 | 2:289-298.

33. Otrock Z, Makarem J, Shamseddine A: Vascular endothelia growth factor family of ligands and receptors:Review. Bllod cells, Molecules and Diseases 2007, 38:258-268.

34. Duraisamy Y, Slevin M, Smith N, Bailey J, Zweit J, Smith C, Ahmed N, Gaffney J: Effect of glycation on basic fibroblast growth factor induced angiogenesis and activation of associated signal transduction pathways in vascular endothelial cells: Possible relevance to wound healing. Angiogenesis 200I, 4:277-288.

35. Ifat S, Tamer L Mink S, Noam A, shivani C Dietmar S, Dina R. Identification of residues important both for primary receptor binding and specificity in fibroblast growth factor-7. I Biol Chem 2003, 275:3488I-34886.

36. West DC, Thompson WD, Sellls PG, Burbridge MF: Angiogenesis assays using the chick chorioallantoic membrane. In Methods in molecular medicine-Angiogenesis: Reviews and Protocols. Edited by: Murray JC. Humana Press; 200I:107-I30.

Publish with Biomed Central and every scientist can read your work free of charge

"BioMed Central will be the most significant development for disseminating the results of biomedical research in our lifetime. "

Sir Paul Nurse, Cancer Research UK

Your research papers will be:

- available free of charge to the entire biomedical community

- peer reviewed and published immediately upon acceptance

- cited in PubMed and archived on PubMed Central

- yours - you keep the copyright

Submit your manuscript here:

http://www.biomedcentral.com/info/publishing_adv.asp
BioMedcentral 